\title{
Del enfrentamiento histórico entre Estado e Iglesia en México al aprovechamiento económico del conflicto cristero a través del turismo religioso
}

\author{
María Genoveva Millán Vázquez de la Torre \\ Profesora Doctora de la Universidad Loyola Andalucía, Sevilla, España \\ gmillan@uloyola.es \\ Rogelio Martínez Cárdenas \\ Profesor Doctor de la Universidad de Guadalajara, Guadalajara, México \\ roy963@hotmail.com \\ Juan Manuel Arjona Fuentes \\ Profesor Doctor de la Universidad Loyola Andalucía, Sevilla, España \\ jmarjona@uloyola.es
}

\begin{abstract}
Resumen Este artículo analiza el conflicto armado entre diversos grupos sociales y el Estado de México (La Guerra Cristera, 1926-1929, cuyo origen fue la aprobación de un decreto nacional que limitaba la actividad y la titularidad de activos inmobiliarios a favor de la Iglesia Católica), asi como el aprovechamiento económico de dicho conflicto a traves de la creación de un producto turístico, "La Ruta Cristera", explotando el movimiento de peregrinación para visitar lugares relacionados con los 25 santos cristeros (personas canonizadas por la Iglesia Católica que fallecieron en dicha guerra) y que cada día tienen más auge principalmente en el pueblo mexicano.
\end{abstract}

Palabras clave: Religión, migraciones, Guerra Cristera, turismo religioso.

\section{Introducción}

Desde la Antigüedad las personas han estado actuando en base a una tricotomía: ${ }^{1}$ seguir los principios de su fe religiosa (mandamientos, preceptos, etc.), personales

1 Dicotomía personal si la persona no es creyente (principios personales y leyes de Estado) 
(entendiendo estos como el conjunto de normas individuales en función de la conciencia de cada uno y que rigen su comportamiento acorde a su forma de pensar y valorar la vida), y las leyes del Estado, muchas veces no estando en consonancia ninguno de los tres (religión-personal-estado), creando conflictos personales sobre cuál debe primar en la voluntad del hombre a la hora de realizar sus actos.

El poder político y el poder religioso deben estar separados, aunque los caminos sean paralelos, para conseguir el fin de ayudar a las personas que están bajo su ámbito (ciudadanos o fieles).

La tolerancia religiosa y la concepción neutral del estado (estado liberal), que respecta de forma ecuánime todas las creencias, es algo que ha ido evolucionando en el tiempo. En la Edad Media el poder religioso en determinadas religiones (especialmente la Cristiana) tenía más fuerza que el poder del Estado sobre la voluntad de los individuos. Siglos después, en el XIX, con la corriente liberal donde los poderes estaban separados y había más armonía, existían países donde esto aún no ocurría, como en Colombia en los años 1849-1954, donde el proyecto liberal fracasó en el aspecto religioso. Según Coy (2007), tres fueron las causas: la primera, la poca repercusión de las leyes anticlericales, que trataban de limitar la influencia de la institución eclesiástica; la segunda, por el tratamiento dado a los altos jerarcas de la iglesia y a los jesuitas; y la tercera, la contradicción entre las nuevas leyes modernizadoras en torno al aspecto social de la religión frente a las actitudes intolerantes del estamento gubernamental. En la actualidad, en las sociedades avanzadas, es el poder del Estado el que gana la batalla al poder religioso a la hora de dirigir la voluntad de los individuos, excepto en países como Irán o Afganistán, donde las normas del estado se rigen por principios religiosos. Lo ideal es que el poder político y religioso estén separados, aunque los caminos sean paralelos para conseguir su fin.

Ya en el siglo XVII, Cromwell, en Inglaterra, indicó que sólo era aceptable la tolerancia religiosa cuando esta no tuviera derecho a intervenir en la vida pública; en Francia, por ejemplo, las persecuciones por motivos religiosos acabaron en la Revolución que sentó las bases de un estado laico, pero no fue hasta 1905, cuando se produce la disociación decisiva entre la Iglesia y el Estado en dicho país.

Las pugnas, por conseguir más poder, han dado lugar a una convivencia tolerada entre ambos. Así, Ríos (2014) indica que la Iglesia Católica, por ejemplo, necesita del poder político para incrementar su influencia y tiene un inmenso poder mediático y adoctrinador, especialmente en países de Latinoamérica; ${ }^{2}$ otras veces es el Estado el que utiliza a la religión como elemento para obtener algunos logros políticos.

En determinadas épocas, por lo tanto,cada poder aprovecha las consecuencias negativas del otro para sacar ventaja en obtener adeptos. Se observa, desde finales del siglo XX, una revitalización de las religiones y espiritualidades (Iranzo, 2013), como consecuencia del debilitamiento del Estado social, además de cierta ruptura de la democracia representativa

2 Ríos (2014) indica que en el siglo XIX, en el estado de Zacatecas, México, hubo muchas disquisiciones sobre la conveniencia o no de aceptar la influencia del orden clerical en el estamento político y educativo, circunstancia que influía en los órdenes sociales y culturales del Estado. 
liberal, el agotamiento de las ideologías, el estrés de coexistir en un mundo "sin sentido" (Beck, 2002). "La sociedad del riesgo" como consecuencia de las fuerzas de globalización y las oleadas migratorias y las formas de vida social desterritorializadas hacen que las personas busquen el refugio en la religión, pues no encuentran amparo en el Estado.

México es un país de fuerte convicción religiosa, donde la influencia de la Iglesia Católica desde la etapa colonial determinó una disputa periódica con el Estado entorno a sus jurisdicciones, excitando duras pugnas en el transcurso del siglo XIX, que culminaron, en el siglo XX, en el conflicto armado efectuado entre los años de 1926 a 1929, el cual enfrentó al gobierno postrevolucionario encabezado por Plutarco Elías Calles y al clero católico y sus fieles. Estos últimos se oponían a las nuevas leyes que se pretendían implementar con el fin de restringir la intervención de la Iglesia Católica en la vida administrativa del país (López, 2011).

Como consecuencia de esta lucha, miles de mexicanos perdieron la vida, unos defendiendo su religión y otros al Estado. Algunos de los que murieron en la contienda han sido elevados a la categoría de mártires religiosos, ${ }^{3}$ creándose movimientos migratorios de peregrinación para visitar sus lugares de nacimiento o de defunción. Cada año miles de peregrinos se desplazan para realizar alguna ofrenda o realizar una petición, generando una corriente económica de ingresos como consecuencia de una disputa entre la religión y el Estado que está siendo aprovechada por ambos poderes: el religioso, mostrando los vestigios de las personas que perdieron la vida por defender su fe, y el político, aprovechando, vía impuestos, los beneficios que genera este segmento turístico de turismo de peregrinación.

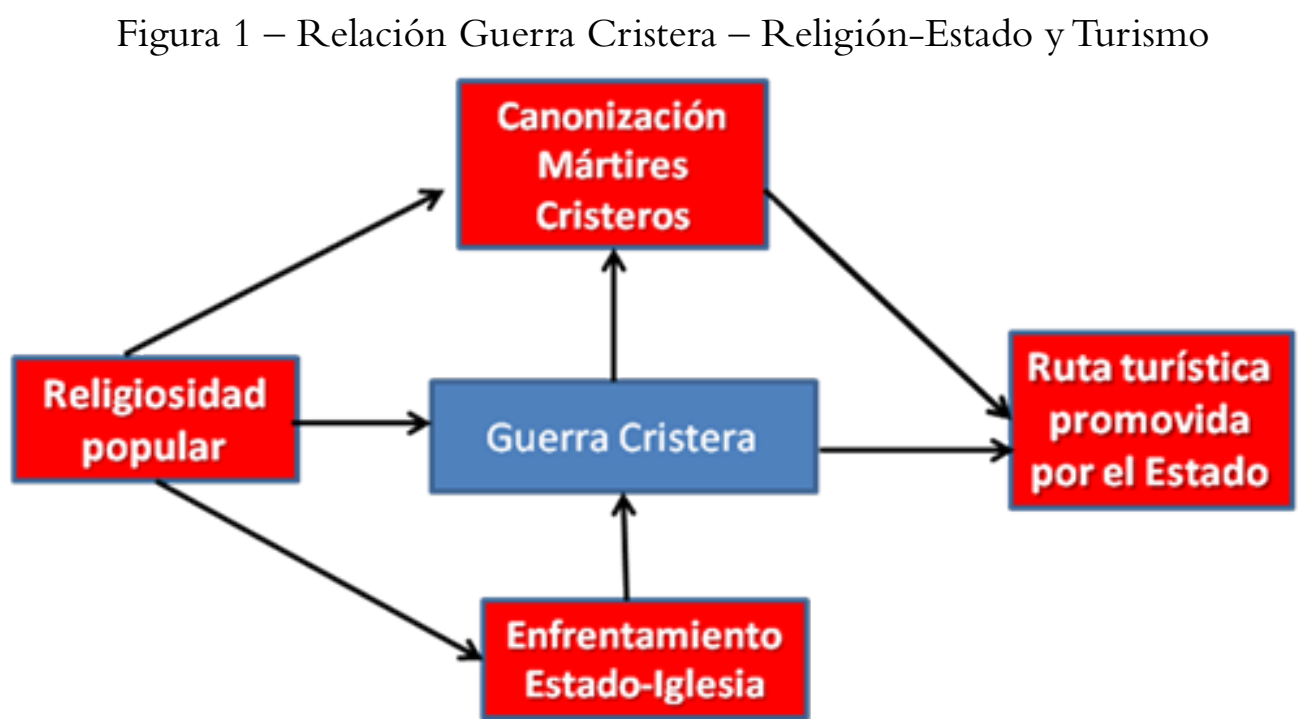

Fuente: Elaboración propia.

3 A partir de 1988 fue cuando México comenzó a tener beatos, entre ellos cuatro católicos. Desde entonces y al parafuas de los papados de Juan Pablo I y Benedicto XVI se adhirieron unos 50 más, lo cuales mayoritariamente eran practicantes entre laicos y eclesiásticos, que habían tomado partido en la guerra cristera. 


\section{Orígenes del movimiento cristero en México}

El asentamiento de los Altos de Jalisco en México se basó en dos esquemas diferentes, pero ambos conformaron para la creación de las características que han dado peculiaridad a esa región. El primero consistió en una migración lenta de españoles, que vinieron a desarrollar la ganadería en la zona; el segundo, mucho más violento, por gente enviada a pacificar a las tribus que habitaban en la zona, además de proteger las caravanas que iban de las zonas mineras a la capital. La forma de retener a la gente fue a través de concesiones de mercedes de tierra, siendo las formas características las peonías, las caballerías y las estancias. A diferencia de la encomienda, las peonías y las caballerías y estancias eran otorgadas en propiedad.

De esa forma se dio origen a una población terrateniente que, a pesar de tener una tierra con pocas cualidades para las actividades agrícolas, permitió el surgimiento del trabajo ganadero como medio de sustento, ya que los españoles y los criollos no consideraban la ganadería como una actividad servil sino, por el contrario, noble (DíazPolanco, 1984; Espín y De Leonardo, 1978; Rendón, 2003).

Con el paso del tiempo, la decadencia de la actividad agrícola y minera provocó que la región alteña se viera afectada en su economía, principalmente por la disminución en el consumo de animales de carga y los derivados de la ganadería que hacían las caravanas mineras, lo que conllevó a algunos dueños de tierras a venderlas y con ello se inició un proceso de concentración de riqueza y formación de una clase social pudiente con una relación cercana a la iglesia, el hacendado mexicano, bienhechor de la Iglesia y que gobernaba un ejército particular (Espín y De Leonardo, 1978).

Muchas han sido las reformas realizadas a nivel estatal, una de ellas la Leyes de Reforma (1857-1861) dieron origen a un conflicto llamado "guerra de reforma" (enfrentado al gobierno "liberal" de corte republicano con grupos conservadores apoyados por el clero, que buscaban el restablecimiento de un gobierno imperial y la conservación de prerrogativas de Iglesia católica). Las nuevas leyes incluían medidas que buscaban la separación de la Iglesia con el Estado. De esta manera, el clero católico vio reducido el papel que había tenido desde la época de la colonia. Uno de los motivos más fuertes de la diferencia entre Iglesia y Estado fue la confiscación de los bienes de propiedad del clero y la abolición de algunas ordenes monásticas, sentando las bases de diversos levantamientos bélicos contrapuestos a cierta legislación de índole liberal, cuyo poso provenía de una corriente opositora marcada por una aversión anticlerical.

En 1917 se promulgó una nueva constitución mexicana, que incluía artículos fundamentados en las máximas de la disociación entre la Iglesia y el Estado (en armonía con la usanza de Carlo III, en España, o la Constitución Estadounidense) retomando ideas anticlericales de los liberales del siglo XIX. La nueva constitución, al igual que la de 1957, abolida la intervención del clero en la política, mantenía la negativa a poseer bienes raíces por parte de la Iglesia, así como realizar cualquier tipo de culto público fuera de los templos. Los sacerdotes tenían prohibido el derecho al voto y la educación primaria 
pasó a ser laica. Pero fue en 1926, con el arribo de Plutarco Elías Calles a la Presidencia de la República, que se refuerzan los controles de intervención de la Iglesia Católica en la vida oficial. Llegó a tal grado la tensión que la diplomacia y las negociaciones se rompen, dando origen a lo que se denominó "cristiada" (Aldana, 1983).

Se conoce como "cristiada" o "guerra cristera" a un movimiento armado que defendió el culto religioso de índole católico romano y que se produjo a finales de los años veinte del pasado siglo, fundamentalmente localizado en la zona centro de México, siendo ésta una de sus revelaciones más conocidas; aunque no siendo la única en la zona de los Altos de Jalisco.

El término "cristero" no sólo está referenciado a aquellos personajes que tomaron partido en el conflicto armado, que tuvo como consecuencia la política religiosa revolucionaria, sino a todo el segmento social que de alguna manera defendió a los que apoyaron la fe católica, incluido los revelados en armas.

Para la concepción de la iglesia el concepto de "cristero" se transforma desde al ámbito más común y mortal al defensor de una causa justa representada por la doctrina común de la población; aún a pesar de emplear métodos poco ortodoxos para la misma religión, todo ello en tiempos de libertad de culto. Según Meyer (2004), por ello los cristeros, lejos de ser considerados mártires, sí que son tenidos en cuenta como héroes de su propia causa.

De acuerdo con la concepción de "cristero", el movimiento cristero en México abarca un período más amplio que el del conflicto armado de 1926 a 1929 por la "defensa de la religión" en contra el Gobierno. Esta etapa sólo representaría el culmen de un añejo enfrentamiento entre iglesia y gobierno, donde quizá el antecedente más remoto de esta lucha se encuentra en el movimiento que encabezó Vasco de Quiroga en contra del régimen de la Nueva España.

La relación entre la Iglesia y el gobierno se fue deteriorando en extremo hasta llegar a un punto que éste último comenzó a perseguir a los sacerdotes que llevaban a cabo su ministerio apostólico, acusándolos de subversión política.

Esta persecución incidió en el adoctrinamiento de los fieles por el clero, infundiendo rebeldía contra el gobierno y suscitando el apoyo a la Iglesia. Entre las medidas para boicotear al gobierno, el clero alentó la desobediencia civil, que incluía no pagar impuestos, evitar o reducir el consumo de bienes promovidos por entidades gubernamentales, así como de billetes de Lotería Nacional, y minimizar el consumo de gasolina con el aminoramiento del uso de vehículos de motor. Todas esas medidas afectaron de forma severa a la economía nacional, pero fue la guerra entre los ciudadanos por defender sus ideas (religiosas o políticas) el gran coste humano y una pérdida irreparable que sufrió el país. Una lucha abierta en el corazón de una nación con una estimación de más de 250 mil fallecidos, entre soldados de la milicia cristeras y ejercito mexicano civiles, que empezó en 1926, con los alzamientos de los estados de Jalisco, Zacatecas, Guanajuato y Michoacán por parte de guerrillas campesinas (cristeros), mal formadas pero conocedoras del terreno, logrando apoyos de la población, que les facilitó el control de algunos pueblos. 
Tras tres años de disputas cruentas, al cabo los cuales los cristeros mejoraron su organización y capacidad militar para enfrentar al ejército gubernamental, vieron su fin tras un convenio entre el gobierno y las jurisdicciones eclesiásticas, poniendo fin a la orden de no poder realizar culto (Miller, 1984).

En la actualidad, las relaciones entre iglesia y estado son aceptables, se toleran mutuamente, los templos pertenecen al estado, pero la iglesia tiene derecho al culto, siendo usufructuaria de los mismos, pero, no obstante, ha habido algunas tensiones especialmente en las campañas de "educación socialista" en el campo, generando pequeños y débiles levantamientos por una parte de la sociedad, siendo una continuidad de la guerra cristera a nivel simbólico, tomando como nombre "la segunda guerra cristera", con el objetivo de no olvidar su libertad religiosa y de culto sobre el poder del estado.

De esta confrontación religiosa ha surgido una serie de templos y monumentos en recuerdo de los mártires y santos cristianos que lucharon por la defensa de su fe, que están siendo aprovechados, bien por la vía espiritual (peregrinación) o por la vida de ocio (turismo) siendo los beneficiados tanto la iglesia, por los óbolos que recibe de sus peregrinos, o el Estado, por los impuestos de las actividades relacionadas con el turismo (comercio, restauración, alojamientos).

\section{Las peregrinaciones como fenómeno migratorio temporal}

Las peregrinaciones por motivos religiosos en México no son algo nuevo ni inherente del país. Desde el principio de las sociedades más primitivas el ser humano ha peregrinado a lugares considerados por él como sagrados, buscando la salud tanto física como espiritual. Ha sido así desde la Prehistoria, donde se tienen vestigios de que el hombre enmarcado en todas y cada una de las antiguas religiones ha peregrinado a lugares sagrados. Se tiene constancia en Asia Menor y Egipto, Grecia, Roma y el Islam. En el caso de las religiones cristianas, el fenómeno toma sentido de la mano de la figura de Cristo, pues Él marca los lugares santos de peregrinación a su paso por este mundo. Las peregrinaciones a Roma vinieron de la mano del culto a los mártires de las Catacumbas y de las visitas de los apóstoles Pedro y Pablo, que fueron, después de Jerusalén, las que más atracción provocaron hasta que el descubrimiento de la tumba del Apóstol Santiago (Rinschede, 1992).

Así, los lugares y ceremonias sagradas se encuentran entre los destinos turísticos más antiguos. No es una característica excepcional de la cristiandad, sino un fenómeno mundial de la historia religiosa (Lanczkowski, 1982).

Antropólogos y arqueólogos han establecido la prueba de este fenómeno entre las sociedades tribales de Europa, Asia, América y Australia en tiempos prehistóricos. Así, menhires, túmulos, crómlechs y pinturas cavernícolas tenían la misma función que tienen hoy las catedrales. Eran centros religiosos que atraían a los fieles, incluso desde lugares muy lejanos (Roussel, 1972). 
Fue en las grandes religiones (el hinduismo, el budismo, el cristianismo y el Islam) donde el turismo religioso obtuvo primero un significado especial como una forma institucional, sobre todo la de la peregrinación, la cual ha ido creciendo en número de devotos en los últimos años.

Por tanto, el turismo religioso y de peregrinación se puede realizar en cualquier parte del mundo, basándose en la religión que profese cada persona; se puede definir como un viaje realizado en tiempo de ocio, motivado parcial o exclusivamente por razones religiosas. La correspondencia entre religión y turismo puede considerarse desde dos aspectos:

- El turismo religioso, como turismo motivado parcial o exclusivamente por razones religiosas (Rinschede, 1992). No es sólo una de las formas más antiguas de turismo, sino que también ha evolucionado, convirtiéndose en un sector importante y creciente del mercado turístico mundial.

- El turismo como religión o como viaje espiritual contemporáneo (Graburn,2001;Haq y Jackson, 2006; Olsen, 2006a, 2006b; Sharpley, 2009). El turismo puede verse desde un punto de vista estructural y funcional como el equivalente moderno del peregrinaje tradicional, siendo la experiencia de liminalidad y communitas comunes a ambos fenómenos; o de forma más general, como una experiencia espiritual moderna que contrasta con la condición anómica de las sociedades (post)modernas (Sharpley, 2009).

La relación entre el turismo y la religión se puede conceptualizar, por tanto, como un proceso basado en la intensidad de los aspectos religiosos principalmente en la motivación, pero también en el comportamiento y uso de elementos religiosos durante el viaje.

En este artículo se analiza como un enfrentamiento entre el poder del estado y la iglesia ha dado lugar a un conflicto armado que ha generado una corriente migratoria de turismo religioso.

\section{El turismo religioso y su implicación internacional}

La importancia e influencia del turismo religioso depende, en gran parte, del número de adeptos y de la distribución geográfica de las diferentes religiones en el mundo, así como del grado de importancia de la religión en cada país, siendo México uno de los más importantes. Cualquier análisis de turismo religioso debería tener en cuentas estos datos (WRTA, 2010).

En la actualidad, la mayoría de los adeptos religiosos pertenecen a alguna de las siguientes tradiciones religiosas: Cristianismo (2,1 billones de seguidores), Islam (1,8 billones), Induismo (900 millones), Budismo (776 millones) y Religión Tradicional China (394 millones). La población no religiosa (agnósticos, ateos,...) estaría formada por 1,1 billones de personas. 
Figura 2 - Distribución geográfica de las principales tradiciones religiosas

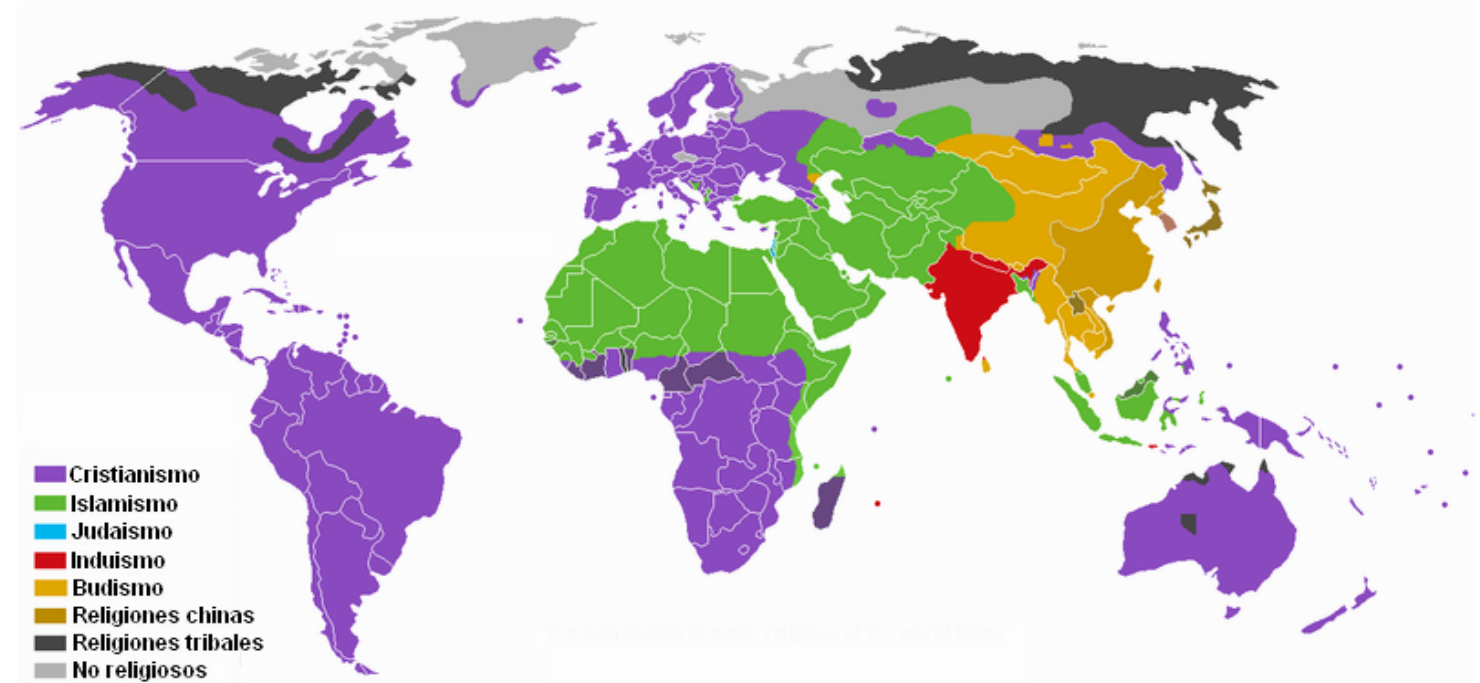

Fuente: Elaboración propia.

La mayor parte de esas tradiciones pueden dividirse en distintas denominaciones:

- ElCristianismo, en Protestantismo,Iglesia ortodoxa,Iglesia Católica y Restauracionismo, entre otras.

- El Islam, Chiismo, en Sunismo, Jariyismo y Sufismo, entre otras.

- La Irreligión, en Agnosticismo, Ateísmo, Humanismo Secular, Racionalismo y Librepensamiento, entre otras.

- El Hinduismo, en Vaishnavismo, Shivaismo, Sij y Smartismo, entre otras.

- El Budismo, en Mahayana, Theravada, y Vajrayana.

La tradición religiosa más extendida es el Cristianismo, tanto en número de creyentes como en distribución geográfica. De ahí que el cristianismo cuente hoy con la mayor parte de los turistas religiosos en el mundo.

La Figura 3 muestra el porcentaje de fieles cristianos que reside en cada país. Sus numerosos seguidores se concentran principalmente en el mundo occidental (Europa, América, Oceanía), África Subsahariana, las Filipinas y Timor Oriental en Asia Suroriental. 
Figura 3 - Porcentaje de creyentes cristianos por país

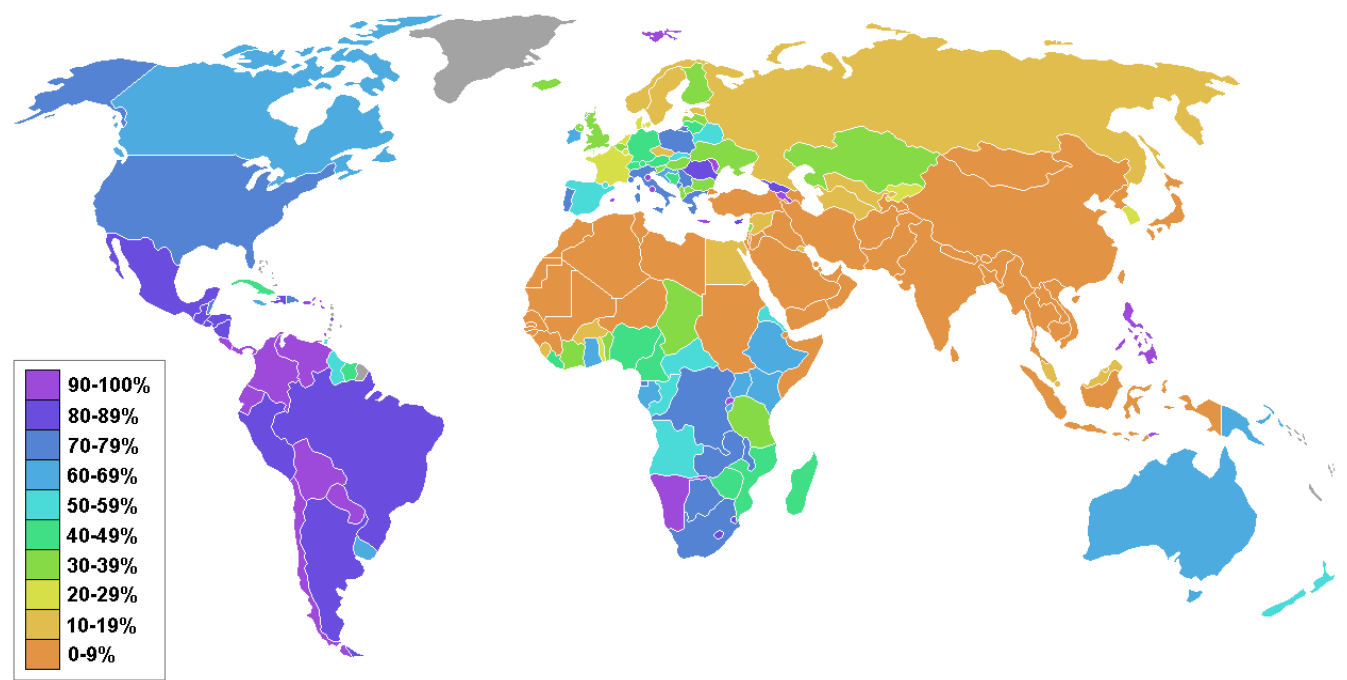

Fuente: Elaboración propia

Dentro del cristianismo la corriente más extendida es la católica (Figura 4). En el año 2007 la cifra de católicos en el mundo ascendía a 1,147 millones de personas, según datos del Anuario Pontificio 2009, considerando que se tiene por persona católica a toda aquella persona bautizada. Más de la mitad de los católicos del mundo se encuentran en América (50\%), el 26\% reside en Europa, el 10\% en Asia, el 13\% habita en África y el 1\% en Oceanía (S. S. Benedicto XVI, 2009).

Figura 4 - Tradición religiosa predominante por país

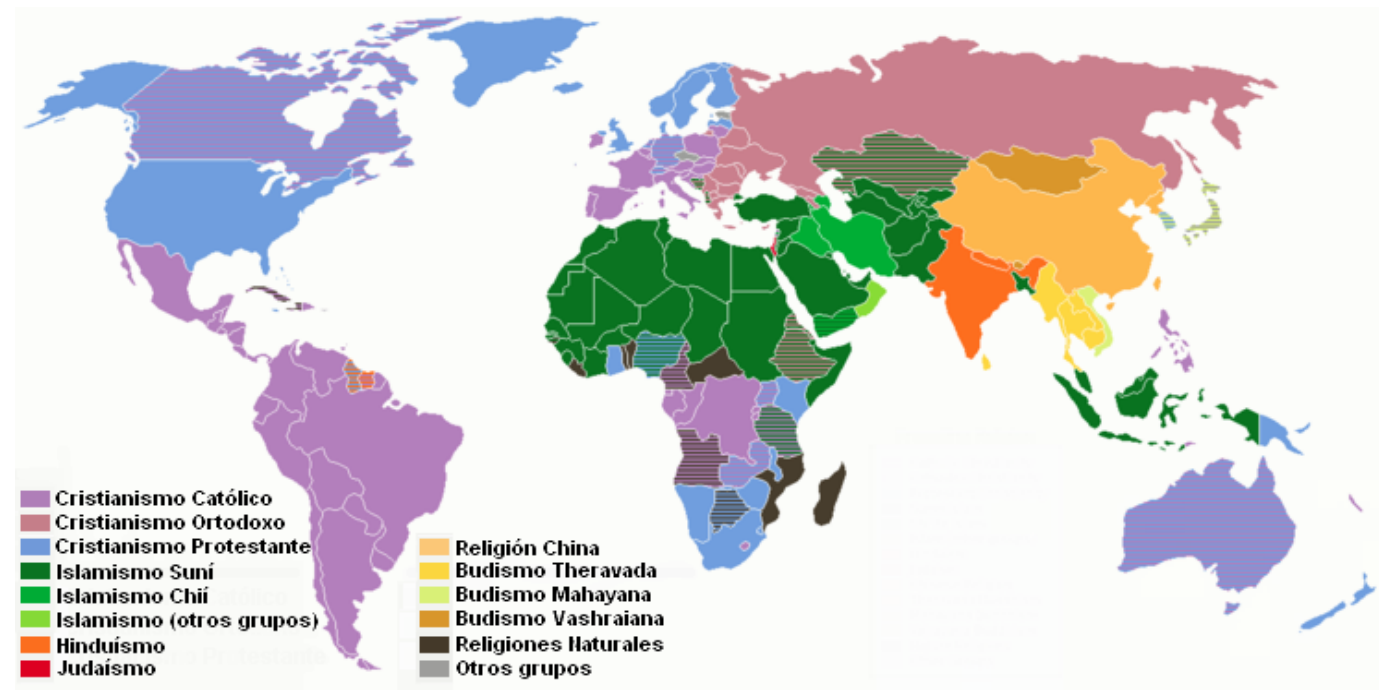

Fuente: Elaboración propia.

Concretamente, el mayor país católico del mundo es Brasil, con un saldo de más de 140 millones de fieles. México, con unos 100 millones de católicos declarados, es el segundo país. Tras ellos se sitúa EEUU, con más de 60 millones, donde buena parte de la población católica es de origen hispano.

Otro dato trascendental a tener en cuenta es la importancia de la religión en cada país, pues hay países que son más religiosos que otros. Es decir, el papel de la religión como parte considerable de la vida cotidiana de las personas puede ser muy diferente 
dependiendo del país del que se trate (Gallup, 2009). En la Figura 5 pueden distinguirse los países más religiosos (en color rojo oscuro) de los menos religiosos (en color rojo más claro).

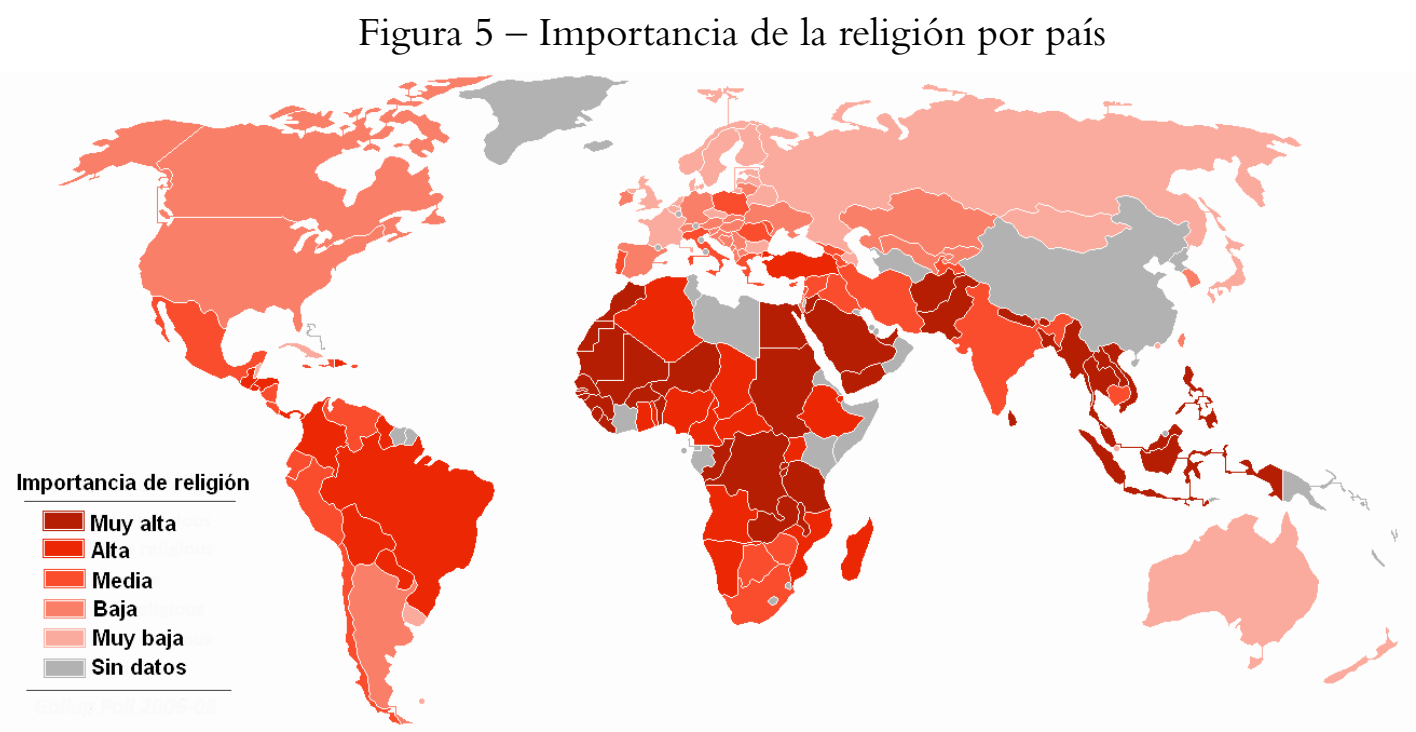

Fuente: Elaboración propia a partir de datos de Gallup (2009).

Según Gallup (2009), “[...] La religión brinda un refuerzo emocional a los pobres del mundo". Los sondeos de Gallup en 143 países revelan que entre los países cuyos ingresos anuales promedio son de 2.000 dólares o menos, el 92\% de los residentes dice que la religión es una circunstancia fundamental de sus vidas diarias, mientras que entre los países ricos encuestados (25,000 dólares al año o más) esa cifra se reduce en un 44\%. ¿Es por tanto la religión el consuelo del pobre? ¿Aprovechan las autoridades religiosas en esos países para influir sobre las conciencias de sus seguidores? ¿Ven los gobiernos de los estados más pobres una amenaza en la religión, por moldear conciencias? ¿Por qué en los países denominados "ricos" las personas son menos religiosas? Preguntas de múltiples respuestas dependiendo de cada cultura, pero van conformando la idiosincrasia de los ciudadanos que la forman.

\section{Beneficios del turismo religioso en la comunidad local}

Aunque no haya una definición universalmente aceptada de turismo religioso, existe un mayor consenso sobre los beneficios que genera para todos los entes implicados. Para las autoridades eclesiásticas los beneficios son evidentes. Por una parte, los destinos pueden conseguir un mayor beneficio en cuanto a donativos y limosnas. El santuario de Lourdes recibe actualmente, entre donativos, ofrendas y herencias, más de 16 millones de euros al año (el 90\% de sus recursos financieros). Por otra parte, el desarrollo del turismo en destinos religiosos se puede concebir como una forma de reafirmar la autoridad de la propia institución religiosa en épocas de debilidad (Covell, 2005; Dahlberg, 1991). Otros ven en el turismo la oportunidad de acercar a la gente a los templos y así atraer a nuevos fieles. Hay, por ejemplo, muchos testimonios de personas que comenzaron el Camino de 
Santiago (España) en un contexto secular y que, sin embargo, terminaron el camino con fuertes sentimientos religiosos, dadas las experiencias vividas durante el viaje y el contacto con otros cristianos.Y otros simplemente muestran su satisfacción por la aportación del turismo y la religión a la sociedad (Millán; Perez, 2017). En este sentido, en una entrevista en 2010 con el Arzobispo Coadjutor de Sevilla, además de Administrador Apostólico de Córdoba (España), Juan José Asenjo Pelegrina, éste manifestaba su alegría respecto a las aportaciones de la Iglesia a la sociedad: "no sólo forma buenos cristianos que siempre serán buenos ciudadanos, sino que también puede ayudar en el campo material dado el impacto que el turismo religioso puede generar en el empleo y en la economía", si bien advertía que este último no debe convertirse en un fin en sí mismo.

Como comenta este arzobispo, el turismo en destinos religiosos no sólo genera beneficios para las autoridades eclesiásticas. El turismo religioso posibilita, por ejemplo, la reactivación de actividades artesanales. El turista religioso siempre ha tenido una verdadera obsesión por llevarse reliquias representativas del destino, desde el polvo del camino hasta el musgo de las puertas de las iglesias o cera de las velas de los altares. Hoy día, son muchos los turistas religiosos que igualmente tienen el deseo de obtener algún recuerdo o dejar en el lugar algún ex-voto. Así, la producción de objetos con carácter artesanal y con motivos típicos del lugar es sin duda una alternativa para corporaciones artesanales tradicionales, así como nuevos términos de arte popular (Robles, 2004).

El turismo religioso favorece, además, la recuperación y preservación de la herencia y riqueza cultural de los pueblos. Las tradiciones religiosas han alimentado el bagaje cultural de los pueblos a lo largo de los siglos (Porcal, 2006). España, por ejemplo, ha recuperado parte de su patrimonio cultural e histórico gracias al desarrollo de productos turísticos como la Red de Juderías, o el Camino de Santiago.

El turista religioso suele ser, también, más leal a los destinos que los turistas de carácter tradicional o con otro tipo de motivación, volviendo al sitio en un periodo de tiempo menor (Robles, 2004).

Por otra parte, Millán, Morales y Pérez (2010) argumentan que el turismo religioso quizás sea el único que puede fortalecerse en épocas de crisis como la actual. Lugares como Guadalupe (México) o Santiago de Compostela (España) han batido récords de turistas en plena crisis económica. Según un estudio elaborado por la organización Gallup (2009), en las poblaciones con más problemas económicos la religión es en realidad una fuerza poderosa y positiva, "una forma literal de seguro social" en tiempos de crisis. En la actual crisis económica, con la angustia que se extiende sobre millones de personas, han sido muchos los que han regresado a los templos. Como Bloch escribió, "cuando hay esperanza, hay religión" (citado porVukonic, 1992).

Por último, Lanquar (2008) subraya que las peregrinaciones y los encuentros religiosos facilitan la admisión de las diferencias entre las personas, lo que estimula la paz entre los pueblos, además que el turismo bien gestionado puede ser un buen instrumento para reducir la pobreza de los pueblos, promoviendo un desarrollo sostenible. 
No obstante, no todo son beneficios. El turismo religioso también conlleva costes importantes, tanto para las entidades que deciden embarcarse individualmente en el desarrollo de esta clase de turismo como para el progreso de infraestructuras de apoyo y de tareas de marketing apropiadas. En conclusión, el desarrollo del turismo religioso obedece, en general, a políticas y programas de organismos gubernamentales, del marketing de organizaciones de turismo o del destino, de gestiones independientes por parte de empresarios y de acciones autónomos por parte de las instituciones religiosas. En algunos lugares, como por ejemplo en Lourdes (Francia), el adelanto del turismo religioso se ha ido formando a raíz de las medidas e iniciativas de autoridades religiosas locales y regionales (Harris, 1999). La planificación estratégica por parte de los directivos de lugares y eventos sagrados es clave para el desarrollo sostenible del turismo religioso de una zona (Ambrosio; Pereira, 2007), sobre todo si se considera la complejidad ampliada a la dirección de estos lugares y eventos donde armonizan religión y turismo (Olsen, 2006a, 2006b; Shackley, 2001).

En resumen,y como se indicaba anteriormente, el turismo religioso o de peregrinación es un fenómeno mundial con gran arraigo histórico en determinados lugares. Puede surgir por diversos motivos, apariciones de la Virgen, milagros de algún Santo o como lugares de martirio en conflictos armados entre Iglesia y Estado (Guerra Cristera). Se aprecia en todas las grandes religiones, así como en las comunidades religiosas y culturales de menor número en cada parte del mundo, no obstante, con una importancia e influencia diferentes.

\section{El turismo religioso en México: importancia estratégica de la región de los Altos de Jalisco}

La posición geográfica que tiene la región de los Altos de Jalisco fue un factor fundamental para su desarrollo, al localizarse en parte de lo que se conoce como "Camino Real de Tierra Adentro" que unía la principal zona minera y la ciudad de México (capital de la Nueva España). Además de ser zona de abastecimiento de mercancías, con la Feria Comercial de San Juan de los Lagos, sirvió como zona de protección para los embarques de oro y plata que circulaban por esta vía (Gutiérrez, 1991).

Por un lado, se unía con Guadalajara (capital de la Nueva Galicia) y el camino hacia las Filipinas. 
Figura 6 - Camino Real de tierra adentro

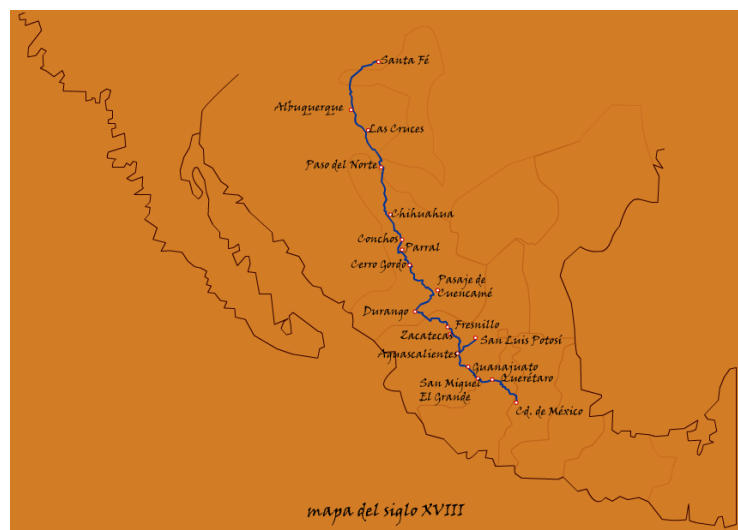

Fuente: http://www.amigosmap.org.mx/wp-content/uploads/2013/05/Camino-Real-de-Tierra-Adentro-.png

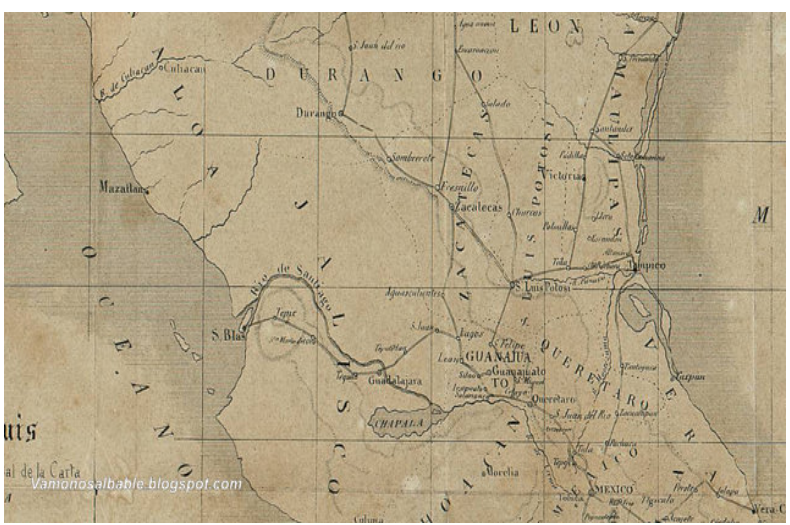

Fuente: http://1.bp.blogspot.com/-4wFDWVSLdTI/UdMr08iTfrI/AAAAAAABDSw/GcSp5JjrbnE/ s640/Captura\%2Bde\%2Bpantalla\%2Bcompleta $\% 2 B 28062013 \% 2 B 01029 . j p g$

Esta región, por su misma ubicación geográfica, quedó fuera del espacio donde se realizaron los conflictos armados que enfrentó el país, como la guerra de independencia (1801-1821), la guerra de reforma (1857-1861) o la revolución (1910-1920), hasta la cristiada (1926-1929), puesto que algunas de las batallas más cruentas se llevaron a cabo en los Altos de Jalisco, además ser el último reducto en rendirse durante este levantamiento.

Aun cuando no cuenta con un gran atractivo de carácter medioambiental o una riqueza patrimonial con valor arquitectónico histórico para que el turismo busque Los Altos de Jalisco como destino turístico, cuenta, desde el siglo XVII, con otro aspecto que le ha permitido tener un flujo de visitantes sumamente importante durante todo ese tiempo, el factor religioso.

\section{El origen del cristianismo en Jalisco}

El mensaje evangelizador llegó a la región alteña a través principalmente de los frailes franciscanos Fray Antonio de Segovia y Fray Miguel de Bolonia. Fue en el año 1573 cuando se creó la parroquia de los Tecuexes o Jalostotitlán, con la cual se independizó del Corregimiento de Teocaltiche y la Alcaldía de Matatán. ${ }^{4}$

La tradición de acudir a los Altos de Jalisco por motivos religiosos tiene su origen en el año 1623, en que se difunde la noticia de un milagro sucedido en San Juan de los Lagos.

El poblado tlaxcalteca que ocupara el territorio que hoy es San Juan de los Lagos (Fábregas, 1986), era un punto intermedio entre dos localidades con población española,

4 Civil y eclesiásticamente, al principio de la colonia la región alteña estuvo sujeta al Corregimiento de Teocaltiche y Alcaldía Mayor de Matatán; luego de fundarse Lagos dependieron de ésta. Lo mismo ocurrió en lo eclesástico, hasta no crearse la parroquia de los Tucuexes o Jalostotitlán, en 1573, que controló los actuales municipios de San Miguel el Alto, San Juan de los Lagos, Valle de Guadalupe, Cañadas y el mismo Jalostotitlán (Gutiérrez, 2001). 
Santa María de los Lagos, donde residía el gobierno civil, y San Salvador de Jalostotitlán, donde estaba asentado el clero que atendía esta comunidad indígena. El principal interés de poblar con gente española ese poblado fue el valor estratégico que tenía al ser punto de confluencia entre la ruta de la plata hacia Europa y la ruta comercial a las Filipinas.

Aun hoy no existe evidencia concreta de la fecha en que se da el milagro atribuido a la imagen hecha de caña de maíz que Fray Miguel de Bolonia dejara en el lugar, pero existe un consenso que debió ser entre 1623 y 1630 . Este hecho marca un hito en la vida de la población al convertirse de manera espontánea en un sitio de peregrinación que sigue recibiendo visitantes hasta hoy día.

Según Fabregas (1986), para desplazar a la población indígena hacia ese lugar, los rancheros ricos y la iglesia inventaron un milagro que realizó la modesta cihuapilli para convertirla en Nuestra Señora de San Juan de los Lagos.

Con el tiempo se crearon dos costumbres: una la de hacer un obsequio a la Virgen, bien dinero, velas (que en aquella época eran escasas y caras), alhajas o exvotos de cera y otra regalar objetos para el culto (Márquez, 1947).

En aquel tiempo de fervor y piedad por parte del pueblo, la Imagen de la Virgen era recibida en todas partes con muestras de alegría, realizando la gente muchísimos donativos de gran valor; su visita era considerada como un beneficio inestimable para la Iglesia. De otros pueblos aledaños empezaron a solicitar que la imagen de la Virgen peregrinara hacia esos pueblos a la vez, y ante la imposibilidad de llevarla a todas partes se decidió, por parte de las autoridades eclesiásticas, realizar otra copia de la original; y las dos Imágenes recorrían a la vez, aunque separadas, las distintas provincias de la Nueva España (Márquez, 1947).

Debido al rápido crecimiento de la devoción a la imagen de la Virgen de San Juan de los Lagos, la capilla existente fue insuficiente, por lo que fue necesario construir un nuevo templo; el responsable de ello fue el párroco Diego Camarena.

La fama y devoción a esta imagen creció a tal grado que para el año de 1655 fueron donados al santuario de San Juan de los Lagos por el capitán Juan de Espíndola y su esposa "mil ovejas de vientre y tijera, las cuales sin disminución alguna permanecían incluidas en los numerosísimos rebaños que tenían en su hacienda San Nicolás de la Torre, Ciénega Grande, los donantes", obligándose a pagar anualmente "como producto de mil pesos en que estimaron las mil ovejas, la suma de cincuenta pesos, destinados para celebrar en el Santuario de San Juan la fiesta de la Asunción de María Santísima a los cielos, con vísperas y una misa muy solemne, con preste, diácono, subdiácono y procesión" (Ruezga; Martínez, 2006).

En el año de 1666 el párroco Verdín de Molina considera que la imagen no corresponde a la de la Asunción de María, sino a la de Purísima Concepción, motivo por el cual cambia la fiesta al ocho de diciembre.

La fe de los peregrinos no se vio afectada por la modificación, que tuvo la advocación mariana de la Virgen de San Juan de los Lagos, ni por el hecho que la fiesta dejara de celebrarse el 15 de agosto para hacerlo ahora el 08 de diciembre. Existe registro del año 
de 1693 en que el capellán Nicolás Arévalo da a conocer al Obispo la participación de treinta sacerdotes en la misa solemne celebrada durante la fiesta. Así mismo, informa que el número de peregrinos que habían llegado era tal que no había forma de hospedarlos en las casas del pueblo (Márquez, 1947).

Años más tarde el Obispo Diez de Sollano propone cambiar de nuevo la fecha en que se lleva a cabo la fiesta, bajo el argumento de que la feria comercial que se realizaba en la primera quincena de diciembre era motivo de mucho desorden y vicios, lo que no correspondían a una fiesta religiosa. Aunque no se cambia la advocación de laVirgen, desde entonces la fiesta de la Virgen se celebra el día dos de febrero de cada año.

\section{La nueva geografía turística religiosa en los Altos de Jalisco}

El conflicto armado denominado "la cristiada" (1926-1929) por muchos años permaneció fuera de los libros de historia de México, pese a que varios actores de la misma, una vez lograda la paz, se convertirían en referentes ideológicos y políticos para las siguientes generaciones.

El Ejército, que representó los intereses del gobierno, tuvo entre sus filas a dos generales anticristeros que unos cuanto años más tarde serían electos presidente de la república. Para el periodo (1934-1940) Lázaro Cárdenas, quien inaugura el periodo sexenal para un presidente y se inmortaliza por la expropiación petrolera. Le sucede en periodo (1940-1946) Manuel Ávila Camacho.

La ideología cristera no muere al terminar el conflicto bélico, es asumida por dos partidos políticos: por un lado, el Partido Acción Nacional (PAN), que profesa el humanismo católico y uno de los principales actores políticos hasta la actualidad, y el Partido Demócrata Mexicano, de breve existencia entre los años 1975 y 1997.

Una vez reanudadas las relaciones del estado mexicano y el Vaticano, y tras un largo proceso de canonización, el 21 de mayo de 2000 Juan Pablo II declara santos a: Atilano Cruz Alvarado, Román Adame Rosales, Julio Álvarez Mendoza, Pedro Esqueda Ramírez, Toribio Romo González, Justino Orona Madrigal, Tranquilino Ubiarco Robles, Sabás Reyes Salazar, José Isabel Flores Valencia, todos considerados mártires por su defensa de la fe durante el conflicto cristero.

A diferencia de otros santos, estos mártires tenían características que no poseían los otros para los pobladores actuales de los Altos de Jalisco: varios de ellos nacieron en esta región, lo que les dio un sentido de pertenencia, además de que en algunos casos todavía existen familiares vivos de ellos. Estos dos hechos fueron fundamentales para la rápida difusión de la devoción a ellos y el surgimiento de santuarios dedicados a su memoria, como el Santuario del Padre Toribio (en Santa Ana de Guadalupe, municipio de Jalostotitlán), el Templo de Cristo Rey y monumento del mismo en La Peñita, municipio de San Diego de Alejandría, el Templo monumento a Cristo Rey, en Cañada de Islas, municipio de Yahualica, el Templo a San Pedro Esqueda, en Teocaltitlán de Guadalupe, 
Municipio de Jalostotitlán, el templo San Tranquilino Ubiarco, en Tepatitlán, la Capilla de San Julio Alvarez, en San Julián, el Templo parroquial de San Román Adame, en Yahualica, y el museo nacional cristero "Efrén Quezada”, en Encarnación de Díaz.

Ante el fenómeno de la rápida devoción a estos nuevos santos, surge la idea de crear la "Ruta Cristera" con su pasaporte cristero, que es un producto turístico desarrollado por la Secretaria de Turismo de Jalisco con la colaboración del Consejo de Fomento y Promoción Turística Zona de los Altos, tratando de emular la Ruta de Santiago en España.

La ruta en realidad corresponde a cuatro circuitos, tratando de abarcar todo el territorio de la región alteña (Figura 7).

Figura 8 - Pasaporte Cristero y Mapa Ruta Cristera

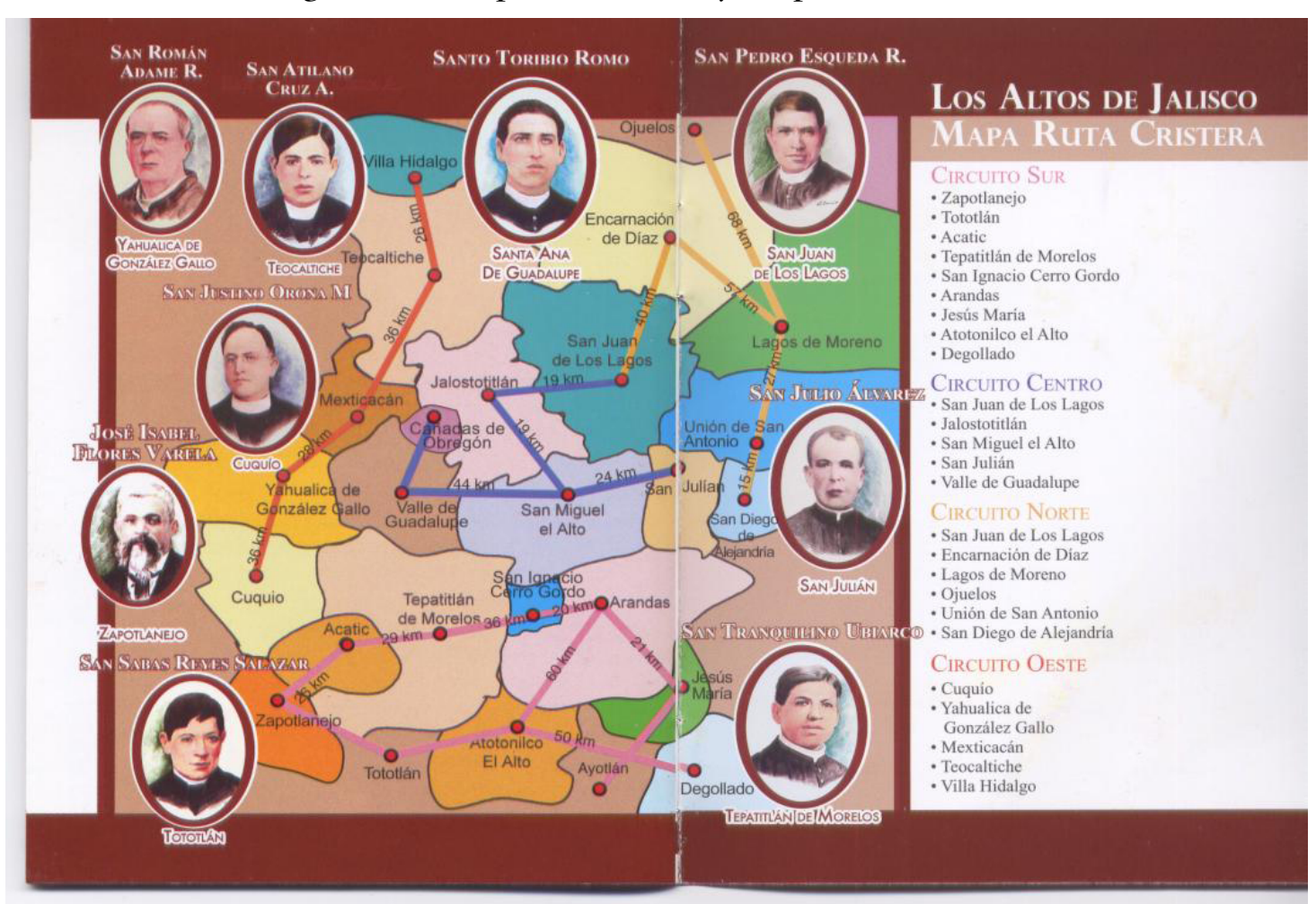

Fuente: Secretaria de Turismo de Jalisco.

\section{Beneficio económico de la Ruta Cristera}

La ruta cristera está formada por un conjunto de municipios donde se encuentran templos erigidos en memoria de los mártires cristeros, ubicados en los Altos de Jalisco. La principal riqueza de la región es la avicultura, cuya producción la coloca como el quinto producto a nivel mundial, también es de destacarse, a nivel nacional, su actividad porcicultora y ganadera, así como la elaboración de tequila, que alcanza importantes cantidades de exportación.

Existe una tradición cultural de migración hacia Estados Unidos (E.U.) debido a que, durante la época de la Segunda Guerra Mundial, existió un programa llamado "bracero", que facilitaba el irse a trabajar a los Estados Unidos, situación que aprovecharon muchos alteños. 
Se calcula que en la actualidad aproximadamente dos millones de personas originarias o de ascendencia de alteña radican en los Estados Unidos. Para evitar esta emigración el gobierno busca vías alternativas de creación de empleo aprovechando los recursos naturales, monumentales, religiosos, etc. de la zona. Siendo uno de ellos el que genera el segmento de turismo religioso proporcionado por las peregrinaciones al Santuario de Nuestra Señora de San Juan de los Lagos (más de 6 millones de peregrinos al año) o a los templos construidos en honor de los mártires cristeros como Santo Toribio Romo (con más de 600 mil visitas al año), con gran devoción por parte de los emigrantes alteños.

El crecimiento del turismo de peregrinación se ve reflejado en cifras económicas, de acuerdo con los datos reportados por la Secretaría de Turismo del Estado de Jalisco, el número de establecimientos reportados a partir del año 2013 y hasta 2017, se ha mantenido una tendencia a la alza desde el año 2007, como se muestra en el siguiente cuadro, donde el número de hoteles ha crecido especialmente los de categoría superior, ya que los de 5 estrellas se han casi triplicado en 10 años (de 9 en el años 2007 a 26 en el año 2017), siendo esto un indicativo de la mejora en el tipo de turista que visita esta región:

Cuadro 1 - Evolución del número de hoteles por categorías en la Región de los Altos (2007-2017)

\begin{tabular}{|l|c|c|c|c|c|c|c|}
\hline \multicolumn{7}{|c|}{$\begin{array}{c}\text { Infraestructura Hotelera Región Altos } \\
\text { Números absolutos }\end{array}$} \\
\hline \multirow{2}{*}{ Categoría } & \multicolumn{7}{|c|}{ Unidades rentables } \\
\cline { 2 - 8 } & $\mathbf{2 0 0 7}$ & $\mathbf{2 0 1 3}$ & $\mathbf{2 0 1 4}$ & $\mathbf{2 0 1 5}$ & $\mathbf{2 0 1 6}$ & $\mathbf{2 0 1 7}$ \\
\hline $\mathbf{5}$ estrellas & 9 & 9 & 9 & 9 & 26 & 26 \\
\hline $\mathbf{4}$ estrellas & 19 & 25 & 25 & 25 & 33 & 35 \\
\hline $\mathbf{3}$ estrellas & 37 & 45 & 45 & 35 & 38 & 41 \\
\hline $\mathbf{2}$ estrellas & 35 & 44 & 44 & 44 & 35 & 35 \\
\hline $\mathbf{1}$ estrella & 57 & 50 & 50 & 50 & 45 & 44 \\
\hline Otras categorías & 52 & 67 & 67 & 67 & 62 & 62 \\
\hline Total & 209 & 240 & 240 & 240 & 239 & 243 \\
\hline
\end{tabular}

Fuente: Elaboración propia con base en los anuarios estadísticos 2013-2017 de la Secretaría de Turismo de Jalisco.

Sin embargo, a pesar del importante incremento que ha tenido el desarrollo de la infraestructura hotelera en la región alteña, pasando de 209 hoteles en el año de 2007 a 243 en el año de 2017 (un incremento 16,26\%), el número de visitantes se ha incrementado en menor proporción, sólo en 15,82\% durante el mismo periodo. Eso hace suponer que el incremento responde más bien a una demanda no satisfecha previa a la creación de la ruta cristera que a un efecto de producto del interés de recorrer la región haciendo la ruta.

Al revisar las cifras de visitantes por mes, los periodos de más afluencia corresponden a las principales fiestas de celebración de la Virgen de San Juan de los Lagos, como son el mes de febrero, por la fiesta de la Candelaria, agosto, por la Asunción de María, y diciembre, por la fiesta de la Virgen de la Concepción, advocación de la imagen. 
Cuadro 2 - Evolución del turismo por meses y años en la Región de los Altos (2013-2017)

\begin{tabular}{|c|c|c|c|c|c|c|}
\hline & 2007 & 2013 & 2014 & 2015 & 2016 & 2017 \\
\hline ENERO & 362.903 & 423.905 & 433.107 & 443.098 & 453.788 & 460.886 \\
\hline FEBRERO & 594.122 & 650.116 & 671.898 & 680.369 & 691.391 & 694.524 \\
\hline MARZO & 415.624 & 442.122 & 455.998 & 466.167 & 476.490 & 782.948 \\
\hline ABRIL & 524.704 & 506.836 & 547.688 & 554.846 & 559.468 & 567.086 \\
\hline MAYO & 249.914 & 239.974 & 246.155 & 252.878 & 262.125 & 265.432 \\
\hline JUNIO & 179.112 & 177.914 & 180.899 & 181.130 & 194.825 & 197.289 \\
\hline JULIO & 395.555 & 440.233 & 445.421 & 456.633 & 463.481 & 469.953 \\
\hline AGOSTO & 506.916 & 531.295 & 534.800 & 536.750 & 549.655 & 557.504 \\
\hline SEPTIEMBRE & 274.406 & 286.623 & 289.636 & 291.815 & 299.692 & 303.964 \\
\hline OCTUBRE & 326.283 & 336.547 & 339.918 & 344.719 & 357.059 & 361.554 \\
\hline NOVIEMBRE & 375.838 & 424.782 & 430.877 & 436.965 & 443.437 & 449.018 \\
\hline DICIEMBRE & 614.737 & 722.906 & 724.618 & 745.057 & 760.458 & 772.399 \\
\hline $\begin{array}{l}\text { TOTAL } \\
\end{array}$ & 4.820 .114 & 5.183 .254 & 5.301 .045 & 5.390 .427 & 5.511 .871 & 5.582 .557 \\
\hline Incremento respecto al 2007 & & $7.53 \% \Delta$ & $9.97 \% \Delta$ & $11.83 \% \Delta$ & $14.35 \% \Delta$ & $15.820 \% \Delta$ \\
\hline
\end{tabular}

Fuente: Elaboración propia con base en los anuarios estadísticos 2007-2017 de la Secretaría de Turismo de Jalisco.

También son periodos importantes para la visita los vacacionales correspondientes a las fiestas navideñas y la semana santa, que puede presentarse en los meses de marzo o abril.

Durante el periodo 2013 - 2017 el promedio de visitantes durante el mes de febrero fue de 677.659 , mientras que agosto ascendió a 542.00 y diciembre a 745.087 . Aun cuando los meses de febrero y diciembre presentan promedios muy similares, la fiesta de la Candelaria tiene un mayor peso como atrayente de visitantes, debido a que en diciembre existe un periodo vacacional de dos semanas por motivo de navidad y año nuevo, que facilita la posibilidad de desplazamiento para los visitantes, mientras que febrero no cuenta más que con un día no laborable, que es el 05 de febrero, fecha en que se celebra la promulgación de la Constitución Mexicana. Es durante esos meses de diciembre y febrero cuando miles de peregrinos se acercan a visitar no sólo el Santuario de laVirgen de San Juan de los Lagos, siguiendo la tradición de hace más de un siglo, sino los nuevos templos creados en honor a los mártires cristeros.

Los ingresos por turismo en la zona de Jalisco $(1.897,73$ millones de pesos, año 2017) suponen el 0,45\% de todos los ingresos por turismo que recibe México $(41.260,87$ millones de pesos), lo que indica que esa región, dado su patrimonio cultural y religioso, se podría explotar más, especialmente en los mercados internacionales, a pesar de que en los últimos 5 años han incrementado en más de 200 millones de pesos los ingresos por turismo en esa zona de los Altos (Figura 8).

El factor religioso está siempre presente en este tipo de visitantes, generando unos ingresos superiores a 1800 millones de pesos, de los cuales más de un 40\% corresponde a turismo religioso. Bien se visite la zona por motivos religiosos o por motivos culturales, la comunidad local se ve beneficiada por los ingresos procedentes del turismo, si no hubiera existido este enfrentamiento Religión-Estado no habría habido mártires cristeros y por lo tanto la Ruta como producto turístico no existiría. 
Figura 8 - Evolución de los ingresos por turismo Región de los Altos (millones de pesos años 2013-2017)

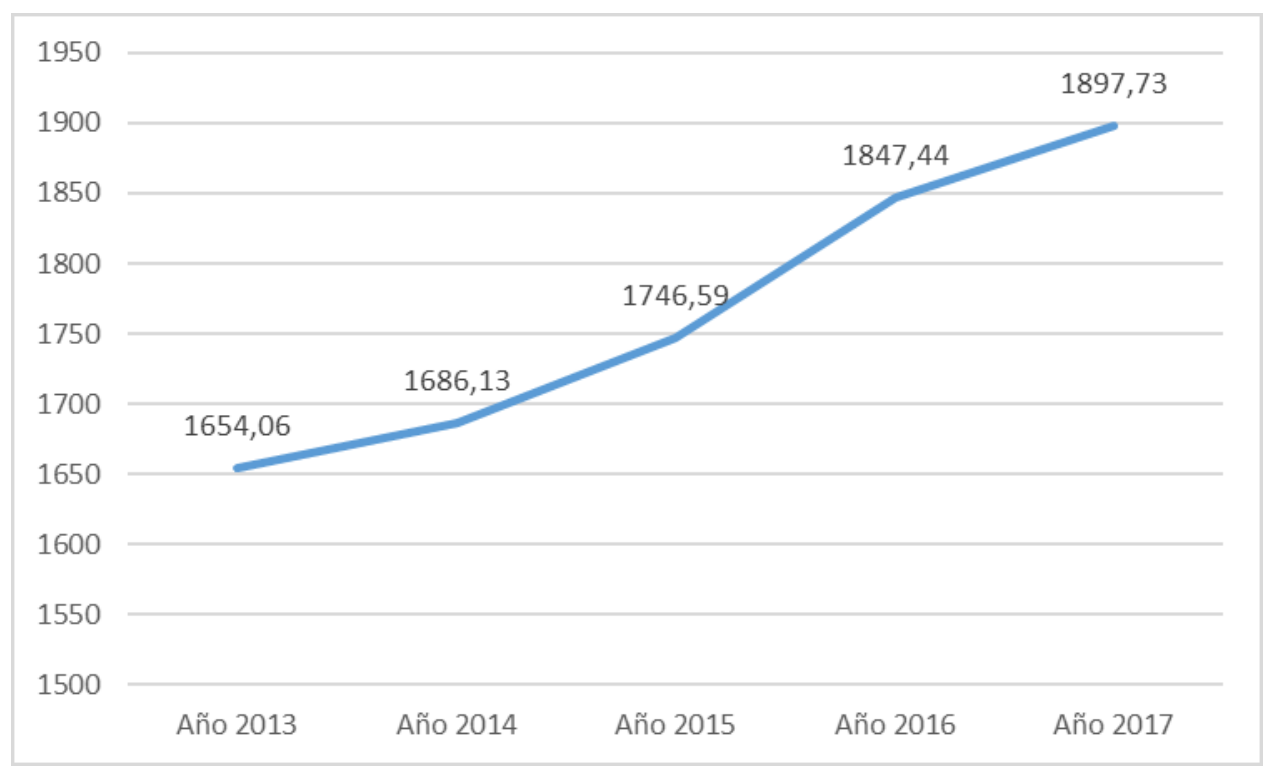

Fuente: Elaboración propia con base en los anuarios estadísticos 2007-2017 de la Secretaría de Turismo de Jalisco.

Tambien es positivo el incremento sufrido en el gasto medio diario por turista (Figura 9), el cual ha pasado de 454,16 pesos en el año de 2013 a 55,21 pesos en el año de 2017 (incremento del 22,2\%), lo que indica que el turista gasta más especialmente en alojamiento de mejor calidad. De ahí que hayan aumentado los hoteles con más estrellas, así como en restauración y comercios de artesania, lo que supone un beneficio para los habitantes del lugar, al ser un turismo de más calidad, que permite crear más empleos y mantener los pequeños negocios de los habitantes cercanos a las zonas religiosas, siendo los recursos obtenidos a traves del turismo religioso, su medio de vida.

Figura 9 - Evolución del gasto medio por turista en la Región de los Altos (millones de pesos años 2013-2017)

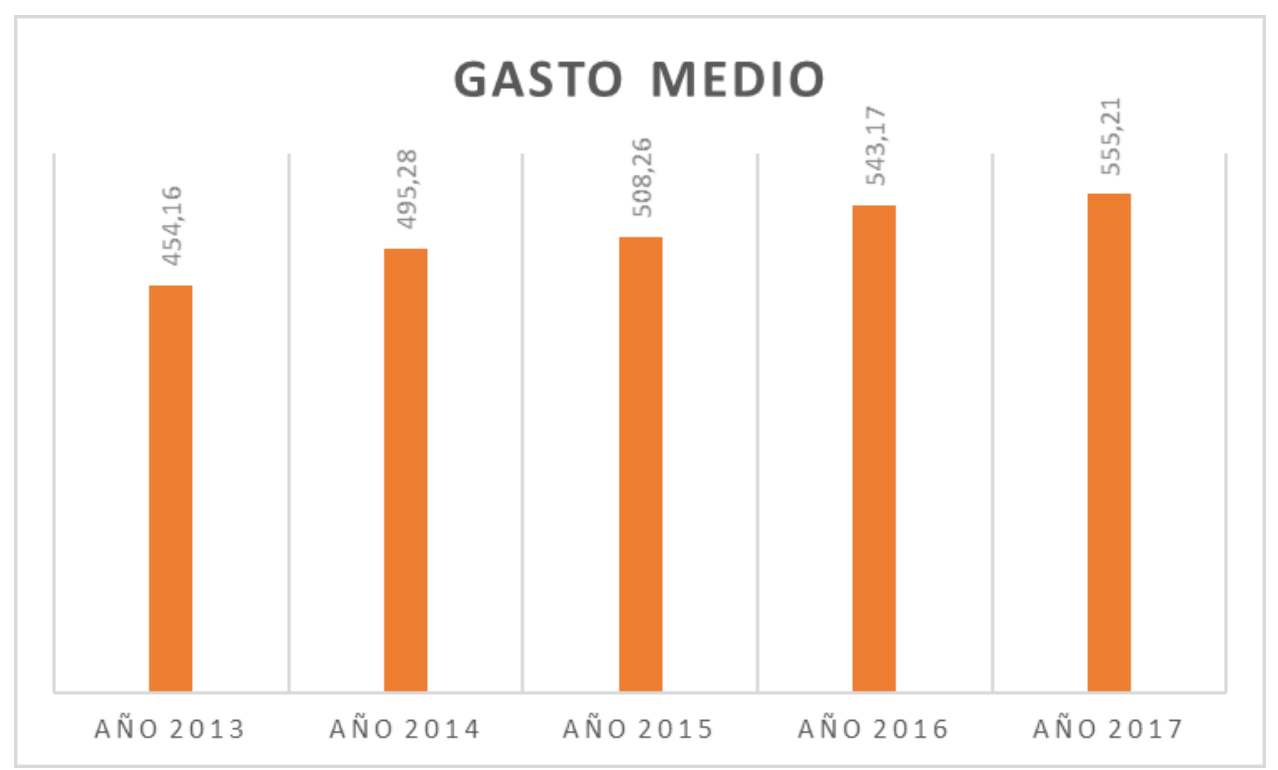

Fuente: Elaboración propia con base en los anuarios estadísticos 2007-2017 de la Secretaría de Turismo de Jalisco. 


\section{Conclusiones}

La lucha por controlar la voluntad del individuo bien a través de la vía coercitiva o moral ha hecho que las distintas religiones y estados (Poder religioso frente al Poder político) hayan estado enfrentándose a lo largo de los siglos.

Las fórmulas actuales de gobernanza, especialmente en los países más avanzados, donde hay una separación entre Religión y Estado, han establecido una convivencia pacífica, no obstante determinadas religiones, cuando toman posturas extremas que distorsionan el sentido original de la misma, como la islámica, hacen que en algunos países del continente asiático o africano las normas del Estado se rijan por las normas religiosas, siendo los líderes religiosos los que ostentan el poder del Estado y gobiernan la nación (causando la involución del país -sirva de ejemplo Afganistán en la época talibán, donde la mujer perdió sus derechos, empobreciéndose el país al perder capital humano, y también se destruyeron esculturas centenarias vestigios de su cultura anterior-).

La religión debe quedar en un uso personal aislado de las normas que rigen la relación entre los países, no se debe ni perseguir, como está ocurriendo en determinados países africanos, a los cristianos o a otras confesiones religiosas, ni englobar un país bajo el manto de una única confesión religiosa. Nos encontramos en un mundo global con globalizaciones de creencias religiosas (Berger, 2005) que están evolucionando, aunque en menor medida de lo que avanza la sociedad, para atender las necesidades particulares de las personas.

Los países deben ser laicos, independientes de cualquier religión, pero deben de atender a las necesidades que las distintas religiones denuncian como representantes de una parte de los ciudadanos, pues en épocas de crisis son las organizaciones religiosas las que más ayudan a los más necesitados (a través de comedores sociales, hospitales, etc., financiadas con donativos de sus fieles), ejerciendo labores humanitarias que deberían de corresponder al Estado.

Cuando un poder sobrepasa la barrera que no le corresponde se está inmiscuyendo en el campo del otro, pues durante muchos años el poder religioso ha sobrepasado al del estado y viceversa.

Uno de esos movimientos para limitar el poder Religioso, en este caso en México, frente al del Estado, llevó a una lucha armada, la "Guerra Cristera", para proteger los derechos de la Iglesia Católica, que fueron abolidos en la Constitución de 1917. El resultado de esta contienda fue miles de muertos de ambos bandos y la recuperación de la Iglesia de algunas de sus libertades, como el derecho al culto, que, al abolirse por parte del estado, entró a regular la parte moral de la persona, al no dejarle ejercer su libertad de derecho al culto religioso que desea, sobrepasando sus funciones.

Como consecuencia de esta guerra algunos de los participantes fueron canonizados, creándose un culto religioso en torno a ellos que genera movimientos de peregrinación, con más de 5 millones de visitas al año, esto ha dado lugar a la creación de un producto turístico, "La Ruta Cristera", que está siendo aprovechado por los dos poderes: el religioso 
(que incrementa sus recursos económicos a través de los donativos que recibe) y el estatal (que incrementa sus ingresos a través de los impuestos que genera ese tipo de turismo de peregrinación).

Una fórmula conjunta que hace que los dos poderes se vean beneficiados por un conflicto que a principios del siglo XX los enfrentó. De la experiencia obtenida por la injerencia de un poder en el campo del otro ha surgido un producto que los ha unido y se ha visto beneficiado con un aumento del número de turistas en los últimos 5 años en la región de los Altos de Jalisco, incrementando el gasto medio por turista, lo que se traduce en una mayor derrama económica de este sector, que está beneficiando a tres colectivos o instituciones: por un lado, a la comunidad local a través de generación de empleo, creación de pequeños negocios de artesanía, restauración, etc.; por otro lado, a las autoridades eclesiásticas a través de los donativos; por último, al gobierno local a través de los impuestos que genera el turismo, una simbiosis positiva de un conflicto negativo (por las muertes causadas) Iglesia-Estado. Como indican García, Solís y Mantilla (2018), el turismo religioso tiene impacto positivo en la sociedad a través de los ingresos aportados por los turistas, que los pueblos deben aprovechar de una forma sostenible para la sociedad local.

\section{Referencias}

AMBRÓSIO,Vitor, PEREIRA Margarida. Case Study 2: Christian/Catholic Pilgrimage - Studies and Analices. En: RAJ, R.; MORPHET, N. D. (Eds.). Religious tourism and Pilgrimage festivals management. Wallingford: CABI, 2007.

ALDANA, Mario. Jalisco durante la República restaurada. Tomo II. México: Universidad de Guadalajara, 1983.

COY, Andrey Arturo. Tolerancia religiosa en Bogotá entre 1849 y 1854. Historia Crítica, v. 33, p. 94-95, 2007.

BECK, Ulrich. La sociedad del riesgo global. Madrid: Siglo XXI, 2002.

BERGER, Peter. Pluralismo global y religión. Estudios Públicos, v. 98, p. 5-18, 2005.

COVELL, Stephen. Japanese temple Buddhism: worldliness in a religion of renunciation. Honolulu: University of Hawaii Press, 2005.

DAHLBERG,Andrea.The body as a principle of holism: three Pilgrimages to Lourdes. En:EADE, J.; SALLNOW, M. (Eds.). Contesting the sacred: the anthropology of Christian Pilgrimage. London: Routledge, 1991.

DÍAZ-POLANCO, Héctor. Agricultura y sociedad en el Bajío. México: Juan Pablos Editor, 1984.

ESPÍN, Jaime; DE LEONARDO, Patricia. Economía y sociedad en los Altos de Jalisco. México: Editorial Nueva Imagen, 1978.

FÁBREGAS, Andrés. La formación histórica de una región, Los Altos de Jalisco. México, D.F: Centro de Investigaciones y Estudios Superiores en Antropología Social, 1986.

GALLUP, Inc. Religion provides emotional boost to World's poor. Washington, DC: Gallup, 2009. Disponible en: http://www.gallup.com/consulting/worldpoll/24046/About.aspx?CSTS=wwwsitemap\&to=SERVIC-GallupWorld-Poll. Acceso en: 1 de julio de 2014.

GARCÍA, Florencio Iván García; SOLIS, Juan Bautista; MANTILLA, Xavier Augusto. Impacto del turismo religioso en la ciudad de Azogues, Ecuador. Caso:Virgen de la Nube. RECIMUNDO, v. 2, n. 1, p. 525-559, 2018. 
GRABURN, Nelson. Secular ritual: a general theory of tourism. En: SMITH,V.; BRENT, M. (Eds.). Hosts and guests revisited: tourism issues of the 21st Century. New York: Cognizant Communication Corporation, 2001. p. $42-50$

GUTIÉRREZ, José Antonio. Los Altos de Jalisco. México, D.F: Consejo Nacional para la Cultura y las Artes, 1991. GUTIÉRREZ, José Antonio. Los Altos de Jalisco.Visión Histórico Cultural, ponencia presentada el 26 de julio de 2001 en el Centro Universitario de los Altos, 2001.

HAQ, Farooq.; JACKSON, John. The recognition of the marketing of spiritual tourism as a significant new area in leisure travel. Paper presented at the Tourism - The Spiritual Dimension Conference, April 5-8, Lincoln, UK, 2006.

HARRIS, Ruth. Lourdes: Body and spirit in the secular age. London: Allen Lane, 1999.

IRANZO, Angela. La comprensión del fenómeno religioso y sus desafios a las Ciencias Sociales. Revista de Estudios Sociales, v. 47, p. 183-190, 2013.

LANCZKOWSKI, Geilige. Die heilige Reise-Auf den Wegen von Gottern und Menschen. Freiburg: Herder Verlag, 1982.

LANQUAR, Robert. Tourism and religions: a contribution to the dialogue among religions, cultures and civilizations - summary of the report prepared in the context of the Conference. En: International Conference on Tourism, Religions and Dialogue of Cultures, Cordoba, Spain, 29-31 October 2007. Madrid:WorldTourism Organization. 2007, p. 197-204.

LÓPEZ, Damian. La guerra cristera (México, 1926-1929). Una aproximación historiográfica. Historiografías, p. 35-52, 2011.

MÁRQUEZ, Pedro. Historia de Nuestra Señora de San Juan de los Lagos. Guadalajara, Jalisco: Litográficos RADI, 1947.

MEYER, Jean. La Cristiada a la distancia. México: Siglo XXI, 2004.

MILLÁN, Genoveva; MORALES; Emilio, PÉREZ, Leonor. Turismo religioso en el Camino de Santiago. Gestión Turística, v. 13, p. 9-37, 2010.

MILLÁN, Genoveva; PÉREZ, Leonor. El turismo religioso en distintas zonas geográficas de España: características de los turistas. Boletín de la Asociación de Geógrafos Españoles, v. 75, p. 29-54, 2017.

MILLER, Barbara. Women in the Mexican Cristerio Rebellión: las señoras y las religiosas. The Americas, v. 40, n. 3, p. 303-323, 1984.

OLSEN, Daniel. Management issues for religious heritage attractions. In: TIMOTHY, D. J.; OLSEN, D. H. (Eds.). Tourism, Religion \& Spiritual Journeys. Great Britain: Routledge, 2006b.

OLSEN, Daniel. Typologies of spiritual tourists. TOURISM - The Spiritual Dimension Conference, Lincoln-UK, April 5-8, 2006a.

PORCAL, Maria Cruz. Turismo cultural, turismo religioso y peregrinaciones en Navarra. Las Javieradas como caso de estudio. Cuadernos de Turismo, v. 18, p. 103-134, 2006.

RENDÓN, María Teresa. Trabajo de hombres y trabajo de mujeres en el México del siglo XX, México. Universidad Autónoma de México (Unam): Programa Universitario de Estudios de Género (PUEG)/Centro Regional de Investigaciones Multidisciplinarias (CRIM), 2003.

RINSCHEDE, Gisbert. Forms of religious tourism. Annals of Tourism Research, v. 19, p. 51-67, 1992.

RÍOS, Rosalía. El ejercicio del patronato y la problemática eclesiástica en Zacatecas durante la Primera República Federal (1824-1834). Historia Crítica, v. 52, p. 47-70, 2014.

ROBLES, Javier. Turismo religioso. Alternativa de apoyo a la preservación del patrimonio y desarrollo. Sincronía, v. 33, p. 1-10, 2004.

ROUSSEL, Claude. Les Ptlerinages. Ed. Que Sais-je?. Paris: Presses Universitaires de France, 1972. 
RUEZGA, Silvano; MARTÍNEZ, Rogelio. El turismo por motivación religiosa en México, el caso de San Juan de los Lagos. Cuadernos de patrimonio cultural y turismo, v. 14, p. 167-176, 2006.

SHACKLEY, Myra. Sacred world heritage sites: balancing meaning with management. Tourism Recreation Research, v. 26, n. 1, p. 5-10, 2001.

SHARPLEY, R. Tourism, religion and spirituality. En:JAMAL, M.; ROBINSON,T. (Eds.). The Sage Handbook of Tourism Studies. London: Sage, 2009. p. 237-253.

WRTA - World Religious Travel Association. "What is WRTA?”. Lexington, KY: World Religious Travel Association, 2010. Disponible en: http://www.wrtareligioustravel.com/WRTA/.Acceso en: 20 de junio de 2014.

\title{
Do enfrentamento histórico entre Estado e Igreja no México à exploração econômica do conflito cristero por meio do turismo religioso
}

\section{Resumo}

Este artigo analisa o conflito armado entre diversos grupos sociais e o Estado do México (A Guerra Cristera, 1926-1929, cuja origem foi a aprovação de um decreto nacional que limitava a atividade y a posse de bens por parte da Igreja Católica), assim como a exploração econômica de tal conflito por meio da criação de um produto turístico, "A Rota Cristera", aproveitando o movimento de peregrinação para visitar lugares relacionados com os 25 santos cristeros (pessoas canonizadas pela Igreja Católica que faleceram nessa guerra) e que a cada dia se tornam mais atrativos, principalmente para a população mexicana.

Palavras-chave: Religião, migrações, Guerra Cristera, turismo religioso.

\section{From the historic struggle between State and Church in Mexico to the exploitation of Cristero conflict through religious tourism}

\begin{abstract}
This article analyzes the armed conflict between various social groups and the State of Mexico (The Cristero War, 1926-1929, whose origin was the adoption of a national decree limiting the activity and ownership of property by the Catholic Church), as well as the economic exploitation of such a conflict by creating a tourism product, "The Cristero Route", taking advantage of the pilgrimage movement to visit places related to the 25 Cristero saints (people canonized by the Catholic Church who died in this war) and which are becoming more popular, especially to the Mexican population.
\end{abstract}

Keywords: Religion, migration, Cristero War, religious tourism.

Data de recebimento do artigo: 22/09/2017 Data de aprovação do artigo: 13/11/2018 